\title{
Induction of early apoptosis and reactive oxygen species (ROS) production by Tanzanian basidiomycete (Cantharellus miomboensis)
}

\author{
Rose MASALU ${ }^{1 *}$, Ken M. HOSEA ${ }^{1}$, Mervin MEYER ${ }^{2}$, Sylvester LYANTAGAYE $^{1}$ and \\ Stonard KANYANDA ${ }^{2}$ \\ ${ }^{1}$ Department of Mol Biology and Biotechnology, University of Dar es Salaam, P.O Box 35179, \\ Dar es Salaam, Tanzania. \\ ${ }^{2}$ Department of biotechnology, University of the Western Cape, Private Bag X17, Bellville 7535, \\ Cape Town, South Africa. \\ *Corresponding author, E-mail: rosemina@amu.udsm.ac.tz; Tel: +255 784534559
}

\begin{abstract}
Cantharellus miomboensis is a new basidiomycete fungus recently found in Miombo woodlands in Tanzania. In this study, crude extract was prepared from fruiting bodies of $C$. miomboensis and was in vitro screened for its cytotoxicity using Tetrazolium salt (3-(4,5-dimethlthiazol-2-yl)-2,5-diphenyl tetrazolium bromide (MTT) in human cell lines namely; Hepatocellular carcinoma (HepG2), Human non-small cell lung carcinoma (H157) and Human colon adenocarcinoma (HT.29). Thereafter, pro-apoptotic effects were determined using biochemical changes in apoptotic cells. These included externalization of phospholipid phosphatidylserine (PS) using APO Percentage dye by flow cytometry and depolarization of mitochondrial membrane potential using Tetramethyl rhodamine ethyl ester perchlorate (TMRE) assay. The test extract was found to induce dose dependent PS externalization on human cell lines when treated with various concentrations $(1-5 \mathrm{mg} / \mathrm{ml})$ and completely depolarized the mitochondrial membrane potential after 6 hours on HepG2 cell line. When the extract was examined for ROS production using 2',7'- dichlorofluorescin diacetate (DCFH-DA) staining, there was no ROS generation found in HepG2 cells. It is therefore concluded that $C$. miomboensis extract is able to induce apoptosis in HepG2 cells and PS externalization and loss of mitochondrial membrane potential in HepG2 cells appear to be independent of ROS production.
\end{abstract}

(C) 2010 International Formulae Group. All rights reserved.

Keywords: Miombo woodlands, apoptosis, basidiomycete, reactive oxygen species, carcinoma.

\section{INTRODUCTION}

Cantharellus miomboensis is basidiomycete mushroom isolate found in miombo woodlands in Tanzania (Tibuhwa, 2009). C. miomboensis is a mycorrhizae fungus and grows only as a symbiont with miombo plants. On the one hand, human consumption of basidiomycete mushrooms has been done for many years and in many parts of the world for dietary and therapeutic purposes. Furthermore, mushrooms are used against physical and mental stress, gastric ulcers, as antioxidants, antimutagenic and as stimulatory of immunity (Asatian et al., 2007; Bruggemann et al., 2006; Yang et al., 2006; Daba and Ezeronye, 2003). The use of mushrooms in the fight against different diseases has been reported in China, Japan, Korea, Russia, USA and Canada (Yang et al., 2006). Mushrooms have also been frequently 
used in traditional medicine in the form of tea and food (Daba and Uzeronye, 2003).

Antitumor and immunomodulating activities have also been demonstrated from mushrooms such as Pleurotus ostreatus and Boletus edulis (Chen et al., 2007). On the other hand, many forms of human cancer diseases are still without cure, and the search for anticancer drugs continues to be the focus of many biomedical and pharmaceutical researchers (Joyce et al., 2001). Cancer is manifested by the uncontrollable growth of cells (tumours) and amongst the various avenues being investigated to tackle cancer cell growth is the induction of apoptosis (also known as programmed cell death). The relationship between apoptosis and cancer has been emphasized with increasing evidence suggesting that the related processes of neoplastic transformation, progression and metastasis involve alteration of normal apoptotic pathways (Sreedhar and Csermely, 2004; Bold et al., 1997). During cancer development, various imbalances can arise in the apoptotic machine. Consequently, sensitivity towards apoptosis is progressively reduced which ultimately leads to inappropriate cell survival and malignant progression (Estelle, 2007; Dickson, 1998).

$$
\text { It is known that many }
$$

chemotherapeutic agents reported exert their antitumor effects by inducing apoptosis in cancer cells (Cande et al., 2002). Studies have shown that induction of apoptosis contributes to anticarcinogenic effects of naturally occurring chemopreventive agents (Chen et al., 2007). It is now estimated that more than 1000 different phytochemicals possess chemopreventive activities (Zhang and Demain, 2005). Emerging evidence also demonstrate increased apoptosis of human malignant tumor cells in the presence of certain chemotherapeutic agents (Demain and Fang, 2000; Demain, 1999).

Despite the search for pro-apoptotic compounds from various sources such as plants (Masoko and Eloff, 2007; Wiyakrutta, et al., 2004), bacteria (Lam, 2006; Robinson, et al., 2001) there are no reported studies yet from Tanzania.

Therefore, this paper reports on the ability of ethyl acetate crude extract from $C$. miomboensis to induce early apoptosis and reactive oxygen species (ROS) production in human cancer cell lines.

\section{MATERIALS AND METHODS \\ Preparation of crude extract}

Fruiting bodies of $C$. miomboensis were collected from Miombo woodlands located in Tabora region, Western Tanzania. The collection was done by hand and the fungi were put into a small basket and brought to the laboratory for identification by a mushroom taxonomist. The specimens were then cut into small pieces and sun dried for three days. The dried materials were then pulverized using a national super mixer grinder (MX-119) (Emerging planet India Ltd., Coimbatore 641011, India). About $200 \mathrm{~g}$ of the powder material were extracted by maceration in $99 \%$ ethyl acetate. The ethylacetate crude extract was then concentrated in vacuo using a rotary evaporator $\left(\mathrm{HEIDOLPH}^{\circledR}\right.$. Essex Scientific laboratory suppliers Ltd) with the bath temperature maintained at $40{ }^{\circ} \mathrm{C}$ as previously described by Muir et al. (2002). The organic extract obtained was kept in a refrigerator at 4 ${ }^{\circ} \mathrm{C}$ until further use.

\section{Cancer cell lines and their culture}

Hepatocellular carcinoma (HepG2), Human non-small lung cell Carcinoma (H157) and Human colon adenocarcinoma (HT.29) cell lines were obtained from culture collection Biochemistry laboratory, Department of Biotechnology, University of the Western Cape, Cape Town, South Africa. A vial of frozen cultured cells was taken from the $-150{ }^{\circ} \mathrm{C}$ freezer. Cells were quickly thawed in a water bath set at $37{ }^{\circ} \mathrm{C}$, until a small amount of ice remained in the vial. The vial was taken to the class II safety cabinet. The cells were then tipped into $25 \mathrm{~cm}^{2}$ tissue culture flask containing prewarmed appropriate culture media, Dulbecco's Modified Eagle Medium (DMEM). The culture media was supplemented with $10 \%$ Fetal Bovine Serum (FBS) and streptomycin/ penicillin (PS) was added at a concentration of $1 \mu \mathrm{g} / \mathrm{ml}$. The flasks were properly labeled and incubated at $37{ }^{\circ} \mathrm{C}, 5 \% \quad \mathrm{CO}_{2}$ humidified incubator for $24 \mathrm{hr}$. The cells were then checked under inverted microscope for bacterial and fungal contamination and whether they had reached confluent. The 
confluent cells were washed with phosphate buffer saline (PBS) without $\mathrm{Ca} 2+/ \mathrm{Mg} 2+$ and trypsinized with $1 \%$ trypsin. Upon addition of trypsin, the cells were incubated for 1 to 2 minutes. Trypsinization was stopped by addition of media containing FBS. The cells were centrifuged and resuspended in trypsin free media.

\section{MTT cytotoxicity assay of $C$. miomboensis extract}

The HepG2, H157 and HT.29 mammalian cell lines was used to evaluate the dose response relationships of the crude extract. The cell monolayers in exponential growth were harvested using 1\% trypsin. Cells were seeded to 96-well plate at a density of 1 x $10^{4}$ cells per $100 \mu \mathrm{l}$ medium and incubated for $24 \mathrm{hr}$ at $37{ }^{\circ} \mathrm{C}$ in a humidified atmosphere of $5 \% \quad \mathrm{CO}_{2}$. After incubation time, the medium was replaced by extract concentrations ranging from $1-5 \mathrm{mg} / \mathrm{ml}$ and $50 \mu \mathrm{g} / \mathrm{ml}$ of camptothecin as a positive control. After treatment, $10 \mu \mathrm{l}$ of the $3-(4,5-$ dimethylthiazol-2-yl)-2,5-diphenyl

tetrazolium bromide (MTT) dissolved in PBS at concentration of $5 \mathrm{mg} / \mathrm{ml}$ was added to each of the microplate well and incubated for $4 \mathrm{~h}$ at $37{ }^{\circ} \mathrm{C}$ in a humidified atmosphere of $5 \%$ $\mathrm{CO}_{2}$. At the end of the incubation period, the media were discarded and $100 \mu$ l of dimethyl sulfoxide (DMSO) added into each well to solubilize formazan crystals. The culture plates were shaken for 5 minutes and optical densities were read at $560 \mathrm{~nm}$ in a Labsystems ${ }^{\circledR} \quad$ Multiskan Bichromatic spectrophotometer. Assays were done in triplicate to ensure reproducibility.

The percentage inhibitions of cell proliferation were calculated using the following formula:

$\%$ inhibition of cell proliferation $=\left(\frac{\text { Absorbanceof sample at } 560 \mathrm{~nm}}{\text { Absorbanceof controlat } 560 \mathrm{~nm}}\right) * 100$

Dose - response curves were plotted from \%IC (Inhibition of cell proliferation values versus concentration of crude extracts $(\mathrm{mg} / \mathrm{ml}) \mathrm{x}$-axis, log scale. Concentrations that inhibit cells proliferation by $50 \%\left(\mathrm{IC}_{50}\right)$ were calculated by locating the $\mathrm{x}$-axis values corresponding to $50 \%$ inhibition of cell proliferation $\mathrm{Y}-$ axis following the standard protocol reported by Buckle and Senders, (1990).

\section{Flow cytometric analysis of apoptosis}

The cells were cultured in a 24 - well plate when they reached $90 \%$ confluence, were treated with extract concentrations ranging from $1-5 \mathrm{mg} / \mathrm{ml}, 50 \mu \mathrm{g} / \mathrm{ml}$ of camptothecin as a positive control and incubated for $24 \mathrm{hr}$ at $37^{\circ} \mathrm{C}$ in a humidified atmosphere of $5 \% \mathrm{CO}_{2}$. Untreated cells were used as negative control. After incubation, the cells were washed twice with PBS to remove the dead cells. They then treated with $1 \%$ trypsin and incubated at $37{ }^{\circ} \mathrm{C}$ for 2 minutes until the cells started to detach from the plate surface. $1 \mathrm{ml}$ of media was added to each well to stop trypsinization and suspend the cell in the solution. Cells then centrifuged for 5 minutes and the supernatant were discarded. The pellet was resuspended with $200 \mu$ l of the Apo dye. The APOPercentage ${ }^{T M}$ dye was prepared by adding $9.5 \mathrm{ml}$ DMEM media to $0.5 \mathrm{ml}$ of the APOPercentage $e^{T M}$ dye. The cells were incubated for 30 minutes at $37{ }^{\circ} \mathrm{C}$ in a humidified atmosphere of $5 \% \quad \mathrm{CO}_{2}$ then washed in $2 \mathrm{ml}$ of PBS and centrifuged for 5 minutes. A volume of $250 \mu \mathrm{l}$ of PBS was added to the pellet and transferred into FACS tube. The cells were then analyzed for dye uptake using FACS (BD Biosciences) instrument. The dye fluorescence was measured by using the FL 2 channels. A minimum of 10,000 cells per sample was acquired and analyzed using CELLQuest PRO software (Biocolor, 2004).

\section{Measurement of mitochondria membrane potential $(\Delta \psi)$ using TMRE}

Cells were seeded at a density of $2.5 \times 10^{4}$ cells per $\mathrm{ml}$ in 24 well culture plates and incubated at $37{ }^{\circ} \mathrm{C}$ in a humidified atmosphere of $5 \% \mathrm{CO}_{2}$ for $24 \mathrm{hr}$. The culture media was then removed and replaced with media containing $3 \mathrm{mg} / \mathrm{ml}$ of fungal extract and $50 \mu \mathrm{g} / \mathrm{ml}$ of camptothecin as a positive control. Untreated cells were used as negative control. The cells were incubated for 30 minutes, $1 \mathrm{hr}, 2 \mathrm{hr}, 4 \mathrm{hr}$ and $6 \mathrm{hr}$ in a humidified $5 \% \mathrm{CO}_{2}$ incubator. Thereafter, the cells were gently washed once with $1 \mathrm{ml}$ PBS. The cells were then trypsinized with $0.5 \mathrm{ml}$ of $0.125 \%$ trypsin, and incubated for $5-10$ minutes at $37{ }^{\circ} \mathrm{C}$ in a humidified atmosphere 
of $5 \% \mathrm{CO}_{2}$ incubator. When the cells were detached, they were transferred into $15 \mathrm{ml}$ tubes and centrifuged for 5 minutes at $3000 \mathrm{xg}$. The pellet was washed twice with $1 \mathrm{ml}$ cold PBS and resuspended in $1 \mathrm{x}$ binding buffer at concentration of $1.0 \times 10^{6}$ cells per ml. A volume of $100 \mu \mathrm{l}$ of cell suspension was transferred into a $15 \mathrm{ml}$ FACS tube and stained with $1 \mathrm{ml}$ of Tetramethyl rhodamine ethyl ester perchlorate (TMRE) and incubated for 30 minutes at room temperature in the dark. TMRE was reconstituted in DMSO to make a stock solution of $50 \mathrm{mM}$. The cells were then acquired and analyzed on a FACSCan $^{\mathrm{TM}}$ (Becton Dickson) instrument equipped with a $488 \mathrm{~nm}$ Argon Laser as a light source. Acquisition was done by setting the Forward scatter (FCS) and side scatter (SSC) on log dot plot to differentiate population of cells and cellular debris. On a linear histogram dot plot, TMRE (FL-1 channel) was measured against relative cell numbers. Negative control cells were used to set the cells in the negative quadrant before all samples were acquired. A minimum of 10,000 cells per sample was acquired and analyzed using CELLQUEST pro-software.

\section{Measurement of reactive oxygen species (ROS) production}

Cells were seeded at a density of $2.5 \times 10^{4}$ cells per $\mathrm{ml}$ in 24 well culture plates and were incubated at $37{ }^{\circ} \mathrm{C}$ in a humidified atmosphere of $5 \% \mathrm{CO}_{2}$ for $24 \mathrm{hr}$. The culture media was then removed and replaced with media containing $3 \mathrm{mg} / \mathrm{ml}$ of fungal extract and $50 \mu \mathrm{g} / \mathrm{ml}$ of camptothecin as a positive control. Untreated cells were used as negative control. The cells were incubated, in a humidified $5 \% \mathrm{CO}_{2}$ incubator. They were then gently washed once with $1 \mathrm{ml}$ PBS. They were trypsinized with $0.5 \mathrm{ml}$ of $0.125 \%$ trypsin, and incubated for $5-10$ minutes at 37 ${ }^{\circ} \mathrm{C}$ in a humidified atmosphere of $5 \% \mathrm{CO}_{2}$ incubator. When the cells were detached, 0.5 $\mathrm{ml}$ of complete culture media was added to the cells to stop trypsinization, transferred into $15 \mathrm{ml}$ tubes and centrifuged for 5 minutes at $3000 x g$. The pellet was washed twice with $1 \mathrm{ml}$ cold PBS. The cells were then transferred into a $15 \mathrm{ml}$ FACS tube and stained with 350 $\mu 1$ of 2',7'- dichlorofluorescin diacetate (DCFH-DA), and incubated for 30 minutes at room temperature in the dark. After incubation, the cells were acquired and analyzed on a FACSCan ${ }^{\mathrm{TM}}$ (Becton Dickson) instrument equipped with a $488 \mathrm{~nm}$ Argon Laser as a light source using FL 2 channel. A minimum of 10,000 cells per sample was acquired and analyzed using CELLQUEST pro-software.

\section{RESULTS}

MTT cytotoxicity assay of $C$. miomboensis MTT Cytotoxicity assay indicates that C. miomboensis caused inhibition of cell proliferation to the three different cell lines tested, HepG2, HT.29 and H157. HT.29 cell line was the most sensitive with $\mathrm{IC}_{50}$ (concentration that inhibit proliferation by $50 \%$ ) of $2.1 \mathrm{mg} / \mathrm{ml}$ followed by $\mathrm{H} 157$ and HepG2 cell lines with $\mathrm{IC}_{50}$ of $\mathrm{IC}_{50} 4.1$ and 5 $\mathrm{mg} / \mathrm{ml}$ respectively as shown in Table 1 .

\section{Measurement of cell surface modifications (externalization of PS) \\ Different cell lines responded differently to apoptosis induction. The externalization of PS was found to be concentration dependent. It was observed that HepG2 cell line was sensitive to the extract of C. miomboensis while H157 and HT.29 were resistant to some extent. A concentration of $2.5 \mathrm{mg} / \mathrm{ml}$ of the crude extract caused $50 \%$ of cell death of the HepG2 cell line; a similar concentration caused $25 \%$ of cell death of the HT.29 and H157 cell lines. The results are shown in Figure 1.}

\section{Mitochondrial membrane potential $(\Delta \psi)$ depolarization}

Treatment of HepG2 cell line with 3 $\mathrm{mg} / \mathrm{ml}$ of $C$. miomboensis resulted into time dependent mitochondrial membrane potential depolarization. Five different time points were used and after $6 \mathrm{hr}$ incubation, 97\% of the cells were depolarized as shown in Figure 2.

\section{ROS production}

Reactive oxygen species (ROS) production varied among the three cell lines tested. In $\mathrm{H} 157$ cell line $50 \%$ of cells produced ROS while in HT.29 and HepG2 cell lines $5 \%$ and $4 \%$ of cells produced ROS, respectively as shown in Figure 3. 
Table 1: $\mathrm{IC}_{50}$ values of $C$. miomboensis after 24 hours treatment on cell lines, measured by the MTT bioassay.

\begin{tabular}{l|lll}
\hline Cell line & H157 & HT.29 & HepG2 \\
\hline IC $_{\mathbf{5 0}}$ & $4.1 \mathrm{mg} / \mathrm{ml}$ & $2.1 \mathrm{mg} / \mathrm{ml}$ & $5 \mathrm{mg} / \mathrm{ml}$ \\
\hline
\end{tabular}

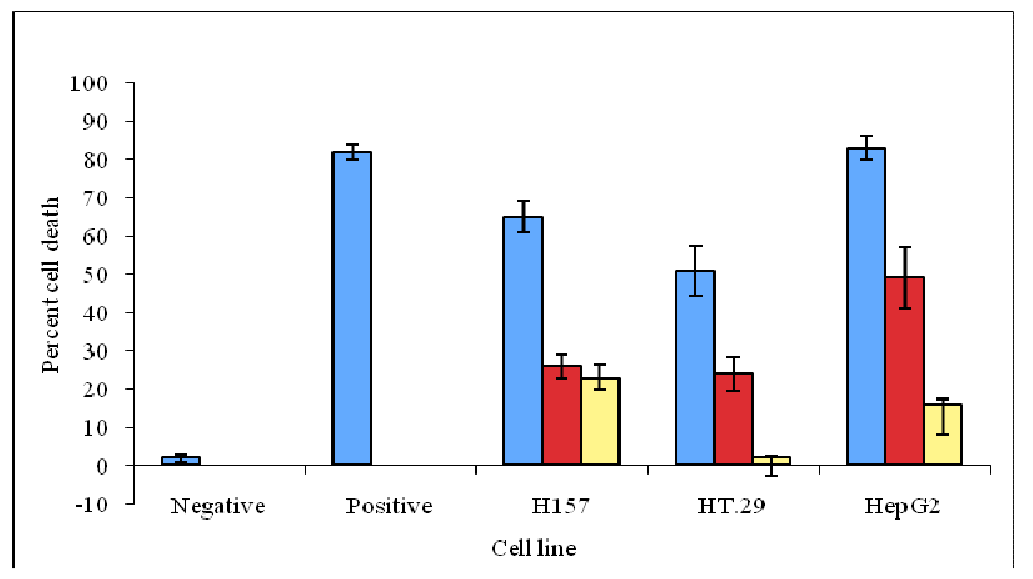

Figure 1: Effects of C. miomboensis on H157, HT.29 and HepG2 cell lines. Blue, Red and Yellow bars represent $5,2.5$ and $1 \mathrm{mg} / \mathrm{ml}$ of $C$. miomboensis extract respectively. The results are presented as mean $\pm \mathrm{SM}$ of three assays.

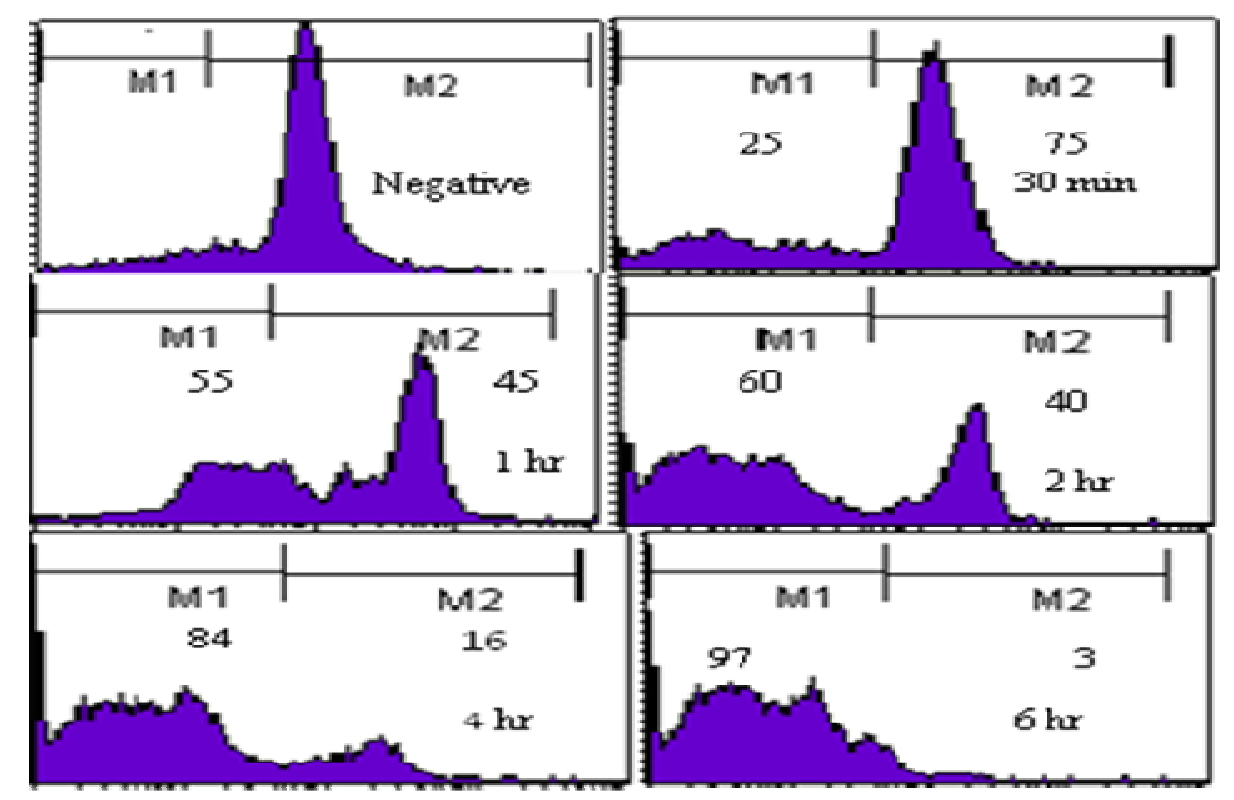

Figure 2: Mitochondrial membrane potential depolarization effects of $C$. miomboensis crude extract up to six hours. 


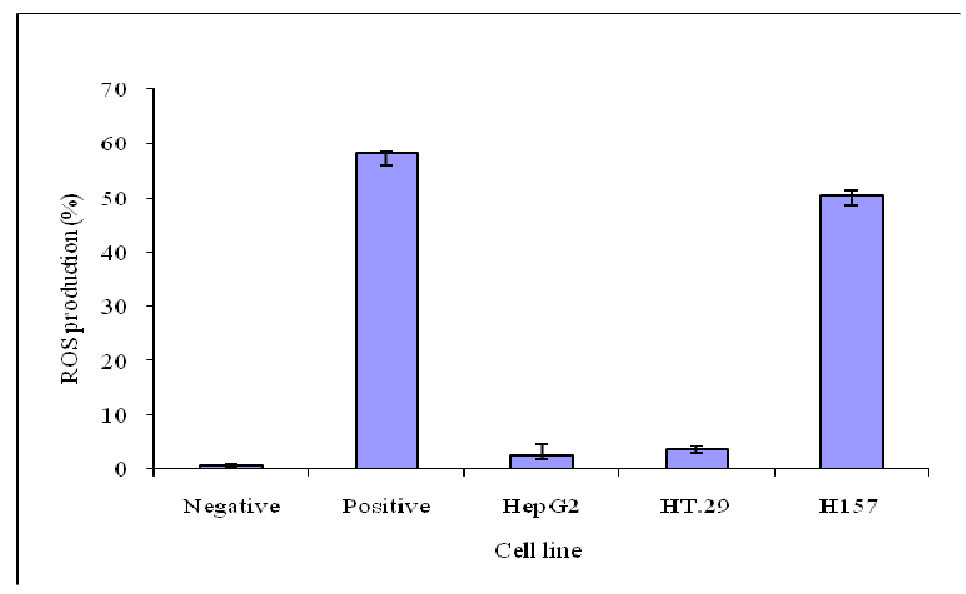

Figure 3: ROS production in HepG2, HT.29 and H157 cell lines after treatment with $3 \mathrm{mg} / \mathrm{ml}$ of $C$. miomboensis for 24 hours. The results are presented as mean \pm SM of three assays.

\section{DISCUSSION}

The in vitro screening approach was adopted in this study due to the fact that, for the last few decades, several in vitro assays using mammalian cell cultures have been developed (Buckle and Senders, 1990), thus avoiding use of laboratory animals, which is expensive, time consuming and often involves ethical problems (Cetin and Bullerman, 2005). Cell culture systems can be more sensitive and more reproducible than tests involving intact animals, they can be used in preliminary screening of toxicity of mycotoxins and elucidation of the modes of action of toxin at the biochemical level related to cellular organelles and are used as toxicity markers (Faller et al., 2002). Cytotoxicity tests generally posses a broad spectrum of sensitivity and are able to detect many toxins which are potentially inhibitors of the biochemical activity of a variety of cultures of animals and human origin (Cetin and Bullerman, 2005).

Previous investigations have demonstrated that the MTT bioassay is an alternative to assay that measure DNA replication based on ${ }^{3} \mathrm{H}$-thymidine incorporation and thus avoids the necessity of handing radioactive materials (Ohno and Abe, 1991). Nevertheless, the MTT bioassay has a better correlation with in vivo assay than the lactate dehydrogenase (LDH) assay previously reported by Faller et al. (2002). Measurement of cell growth by MTT reduction in this study has correlated well with indices of cellular protein and viable cell number (Hanelt et al., 1998). Cell inhibition proliferation varied among the cell lines used in this study. The most sensitive cell culture model to evaluate the cytotoxic effect of $C$. miomboensis was HT.29 with the concentration that kill $50 \%$ of the cells $\left(\mathrm{IC}_{50}\right)$ of $2.1 \mathrm{mg} / \mathrm{ml}$. HepG2 was found to be less sensitive with $\mathrm{IC}_{50}$ of $5 \mathrm{mg} / \mathrm{ml}$. The results are comparable with the results reported by Cetin and Bullerman, (2005) where less sensitivity of HepG2 cells was observed in cytotoxicity tests of Fusarium toxin, zearalenone (ZEN).

One of the early events happening when a cell is undergoing apoptosis is the rapid flipping of the membrane phospholipid phosphatidylserine (PS) from inner to outer leaflet of the membrane (Fadok et al., 1992). In the presence of APOPercentage ${ }^{T M}$ dye this event allows the dye to enter and get trapped inside the intact cell membrane of the apoptotic cells (Biocolor, 2004). When this stage has passed, no more of the dye enters the cell, and the dye, which has entered is trapped inside the intact cell membrane. This feature makes, the assay a useful detection and quantification tool to monitor the occurrence of apoptosis in vitro (Biocolor, 2004; Joyce et al., 2000).

In this study, the externalization of membrane phospholipids phosphatidylserine (PS) by $C$. miomboensis crude extract was found to be dose dependent on mammalian 
cell lines H157, HT.29 and HepG2 tested. It was observed that $5 \mathrm{mg} / \mathrm{ml}$ of the crude extract was able to induce apoptosis characterized by translocation of PS molecules in all three cell lines tested. Results are consisted with biochemical characteristics of apoptosis that PS externalization is sensitive event during cascade of apoptosis (Cande et al., 2002). Furthermore, it was observed that at lower concentration $C$. miomboensis extract induce apoptosis to $50 \%$ of HepG2 cell line and only $25 \%$ of HT.29 and H157 cell lines. This could be explained by the fact that the apoptotic signaling pathway for HepG2 is different from that of H157 and HT.29 cell lines (Chen et al., 2007). Mitochondrial outer membrane depolarization regulated by $\mathrm{Bcl}-2$ family members is an integral event during apoptosis (Cory and Adams, 2002, Waterhouse et al., 2001). Upon depolarization, the outer membrane become permeable, then cytochrome $\mathrm{c}$ is released to facilitate formation of the apoptosome and caspase activation and finally apoptosis takes place (Gill et al., 2006). The crude extract of $C$. miomboensis was investigated in the present study for mitochondrial depolarization using HepG2 cell line. There was complete depolarization of mitochondrial membrane after $6 \mathrm{hr}$ incubation period. It was further revealed after $2 \mathrm{hr}$ more than half of the cells lost their mitochondrial membrane potential (Figure 2). Results support observations from previous studies by Sreedhar and Csermely, (2004), Waterhouse et al. (2001) that mitochondrial affected early during apoptotic process and they are thought to act as central regulators of cell death. Several pro-apoptotic signal transductions and damage pathways converge on mitochondrial to induce mitochondrial membrane permeabilization thereby triggering the release of potentially toxic mitochondrial proteins (Motadi et al., 2007).

It is known that oxidative stress is implicated in a huge variety of natural and pathological processes, including apoptosis (Atsumi et al., 2006). Cumulative evidence indicates that Reactive Oxygen Species (ROS) may play a role as trigger or signaling molecules in mitochondria death receptors and p53 modulated apoptosis (Nordberg and Arner, 2001). In this sense, we studied the formation of intracellular ROS by $C$. miomboensis in HepG2, HT.29 and H157 cells lines. The results reported herein reveal that C. miomboensis induce about $50 \%$ of ROS in $\mathrm{H} 157$ and no ROS production was observed in HepG2 and HT.29 cell lines (Figure 3). Results suggest that $C$. miomboensis might possess protective antioxidant properties. However, as described above, the strain induced ROS production in the H157 cell line. Thus, the active components in this strain might serve as mediators of the reactive oxygen scavenging system and have the potential to act as a prooxidant and an antioxidant depending on the redox state of the cell line. Such dual property of antioxidants has also been previously reported by other workers in the field (Chen et al., 2007; Kurosumi et al., 2007).

In this study, it was demonstrated that C. miomboensis is able to induce apoptosis in cancer cell lines. Since one of the most promising targets for cancer therapy is apoptosis, C. miomboensis could be potential sources of novel anticancer drug leads.

\section{Conclusions}

These results are presented to draw attention to miombo forest fungi such as $C$. miomboensis, studies are needed to domesticate and promote human consumption of this forest fungus. To determine common or several functional pathways in which apoptosis is being induced by $C$. miomboensis. Furthermore, there is need for follow up studies to purify and conduct chemical studies on $C$. miomboensis extract whose potential has been uncovered in this study.

\section{ACKNOWLEDGEMENTS}

We thank UDSM/Norway Supported Human Resource Capacity Development Program at University of Dar es Salaam, for a PhD scholarship to the first author, Rose Masalu. We would also like to express our gratitude to the Third World Organization for Women in Science (TWOWS) for a fellowship that enabled Rose Masalu to conduct laboratory experiment in South Africa. 


\section{REFERENCES}

Asatian MD, Elisashvili VI, Wasser SP, Reznick AK. 2007. Free-Radical Scavenging Activity of Submerged Mycelium Extracts from Higher basidiomycetes Mushrooms. Biosci. Biotechnol. Biochem., 71: 3090-3092.

Atsumi TK, Tonosaki K, Fujisawa S. 2006. Induction of early apoptosis and ROSgeneration activity in human gingival fibroblast (HGF) and human submandibular gland carcinoma (HSG) cells treated with curcumin. Achives of Oral Biol., 51: 913-921.

Biocolor 2004. APOPercentage manual. Newtownabbey Northern Ireland, Biocolor Ltd.

Bold RJ, Termuhlen PM, McConkey. 1997. Apoptosis, cancer and cancer therapy. Surgery Oncol. 6: 133 - 142.

Bruggemann R, Orlandi MJ, Benati JF, Faccin CL, Mantovani SM, Nozawa C, Linhales A. 2006. Antiviral activity of Agaricus Blazei Murrill ss. Heinem extract against human and Bovine Herpesviruses in cell culture. Brazillian J. Microbiol., 37: 561565.

Buckle AE, Senders MF. 1990. An appraisal bioassay method for detection of mycotoxins- review. Letters Appl. Microbiol., 10: 155-160.

Cande C, Cecconi F, Dessen P, Kroemer G. 2002. Apoptosis inducing factor (AIF): Key to the conserved caspase independent pathways of cell death. $J$. cell sci, 115: 4727 - 4734.

Cetin Y, Bullerman LB. 2005. Cytotoxicity of Fusarium mycooxins to mammalian cell cultures as determined by the MTT bioassay. Food Chem. Toxicol., 43: 755764.

Chen C, Chang W, Liu T, Wu CC, Cheng JT, Yiin SJ, Shih MK, Wu MJ, Chern CL. 2007. Isoobtusilactone A-induced apoptosis in human hepatoma HepG2 cells is mediated via increased NADPH oxidase-derived reactive oxygen species (ROS) production and the mitochondrialassociated apoptotic mechanisms. Food Chem. Toxicol., 45: 1268-1276.

Cohen JJ. 1999. Apoptosis: Mechanisms of life and death in the immune system. $J$. Allegy Clinical Immunol., 103: 548 - 554.
Cory S, Adams JK. 2002. The Bcl-2 family: regulators of the cellular life or death switch. Nature Rev. Cancer., 2: 647 656.

Daba AS, Ezeronye OU. 2003. Anti-cancer effect of polysaccharides isolated from higher Basidiomycetes mushrooms. Afr. J. Biotechnol. 2(12): 672-678.

Demain AL. 1999. Pharmaceutically active secondary metabolites of microorganisms. Appl. Microbiol. Biotechnol., 52: 455-463.

Demain AL, Fang A. 2000. The natural functions of secondary metabolites. In Advanced Biocheml. Eng. Biotechnol., 69: 1-39.

Dickson AJ. 1998. Apoptosis regulation and its application to biotechnology. Trends. Biotech., 16: 339-342.

Duke RC, Ojcius DM, Young, YD. 1996. Cell suicide in health and disease. Sci. American., 275: 80 - 87.

Estelle S, Claudie P, Myriam M, Richard B. 2007. DNA - damage response network at the crossroad of cell-cycle checkpoints, cellular senescence and apoptosis. $J$. Zhejiang University Sci., 8: 377-397.

Fadok VA, Savill JS, Haslett C, Bratton DL, Henson PM. 1992. Different populations of macrophages use either the vitro nectin receptor or the phosphatidylserine receptor to recognise and remove apoptotic cells. J. Immunol., 149: 40294035.

Faller C, Bracher M, Dani N, Roguete R. 2002. Predictive ability of reconstructed human epidermis equivalents for the assessment of skin irritation of cosmetics. Toxicol. in vitro, 16: 557-572.

Gill C, Meyer M, FirtzGerald U, Samali A. 2006. The role of heat shock proteins in the regulation of apoptosis. Mol. Biol. Approach., 4: 81 - 308.

Hanelt M, Gareis M, Kollarczik B. 1998. Mycotoxins evaluated by the MTT - cell culture assay. Mycopathologia, 128: 167 174.

Joyce DE, Gelbert L, Ciaccia A, De Hoff B, Grinnel BW. 2001. Gene expression profile of anti-thrombotic protein $\mathrm{c}$ defines new mechanisms modulating inflammation and apoptosis. J. Biol. Chem., 276: 11199 - 11203. 
Kurosumi A, Sasaki C, Kumada K, Kobayashi F, Mtui G, Nakamura Y. 2007. Novel extraction method of antioxidant compounds from Sasa palmata (Bean) Nakai using steam explosion. Process Biochem., 42: 1449-1453.

Lam KS. 2006. Discovery of novel metabolites from marine actinomycetes. Curr. Opin. Microbiol, 9: 245-251.

Masoko P, Eloff JN. 2007. Screening of twenty-four South African Combretum and six Terminalia species (combretaceae) for antioxidant activities. Afri. J. Trad Compl Alternative Med, 4: 231-249.

Motadi LR, Misso NL, Dlamini Z, Bhoola KD. 2007. Molecular genetics and mechanisms of apoptosis in carcinomas of the lung and pleura: Therapeutic targets. International Immunopharmacol., 7: 1934 - 1947.

Muir JC, Pattenden G, Ye T. 2002. Total syntesis of (+)-curacin A, a novel antimitotic metabolite from a cyanobacteria. J. Chem. Society Perkin Trans., 1: 2243 - 2250.

Nordberg J, Arner ESJ. 2001. Reactive oxygen species, antioxidants and the Mammalian Thioredoxin system. Free Radical Biol. Med. 31(11): 1287-1312.

Ohno M, Abe T. 1991. MTT cell proliferation assay. J. Immuol. Methods., 145: 199203.

Robinson T, Singh D, Nigam P. 2001. Solid state fermentation: a promising microbial technology for secondary metabolite production. Appl. Microbiol. Biotechnol., 55: 284-289.
Sreedhar SA, Csermely P. 2004. Heat shock proteins in the regulation of apoptosis new stratergies in tumor therapy, A comprehensive review. Pharmacol Ther., 101: $227-257$.

Tibuhwa DD. 2009. Taxonomic studies on Cantharellus (Mushrooms) from the miombo woodlands of Tanzania. $\mathrm{PhD}$ Thesis, University of Dar es Salaam, Dar es Salaam. 179p.

Waterhouse NJ, Goldstein JC, Von Ahsen O, Schular M, Newmeyer DD, Green DR. 2001. Cytochrome C Maintains Mitochondrial Transmembrane Potential and Atp generation after Outer Mitochondrial membrane Permeabilization during the Apoptotic Process. J. Cell Biol., 152(2): 319 - 328.

Wiyakrutta S, Sriubolmas N, Panphut W, Thongon N, Danwisetkanjana K, Rungrungsi N, Meevootisom V. 2004. Endophyic fungi with anti-microbial, anticancer and anti-malaria activities isolated from Thai Medicinal Plants. World J. Microbiol. Biotechnol., 20: 265272.

Yang L, Chen C, Chang W, Liu T, Wu CC, Cheng JT, Yiin SJ, Shih, MK, Wu, MJ, Chern CL. 2006. Growth inhibition and induction of apoptosis in MCF-7 breast cancer cells by Antrodia camphorate. Cancer lett., 231: 215 - 227.

Zhang L, Demain AL. 2005. Natural Products: Discovery and Therapeutic Medicine $\left(2^{\text {nd }}\right.$ edn). Humana Press Inc.: Totowa. 